\title{
Halfway up the highway: Can Nepal meet its Health Millennium Development Goals?
}

\author{
Vaidya A, Jha ${ }^{2}$ \\ 'Department of Community Medicine, Kathmandu Medical College, Duwakot, ${ }^{2}$ Department of Community Medicine, BP Koirala \\ Institute of Health Sciences, Dharan, Nepal
}

\begin{abstract}
The Millennium Development Goals (MDGs) are international objectives on poverty reduction adopted by the world community and provide the broad context for this revolution in thinking and practice. The MDGs place a central focus on public health, in recognition of the fact that improvements in public health are vital not only in their own right but also to break the poverty trap of the world's poorest economies. Nepal has been committed to achieving the MDGs since it endorsed the Millennium Declaration. As we have at present just passed the midway through the 15 years to MDGs deadline of 2015, this article reviews the status of Nepal in achieving the MDGs, the challenges it faces and whether it can achieve the MDGs by 2015.
\end{abstract}

Key words: development, goals, health, millennium, Nepal

\section{INTRODUCTION}

Health for All by the year 2000 has been in existence for more than 25 years since the Alma Ata declaration when it was stated that 'inequality in the health status of people, particularly between developed and developing countries as well as within countries, is politically, socially and economically unacceptable'. ${ }^{1}$ Yet, Health for All remains an elusive goal and large and growing disparities in health persist both within and between the countries. ${ }^{2}$ With the failing Health for All by 2000 , the stakeholders around the globe realized the need to readdress the problems of health, poverty and overall human development in a more holistic manner. Many targets were set and compiled in the 1990s in to what was known as the International development Goals. But it was only at the turn of the millennium that the Member States of the United Nations adopted the Millennium Declaration from which the Millennium Development Goals (MDGs) were drawn. ${ }^{3}$ The MDGs are a groundbreaking international development agenda for the $21^{\text {st }}$ century and outline the major developmental activities and priorities to be achieved by the year 2015.4

The MDGs place a central focus on public health, in recognition of the fact that improvements in public health are vital not only in their own right but also to break the poverty trap of the world's poorest economies. Three out of the total 8 goals, eight out of the total 18 targets and 18 out of the 48 indicators are explicitly about health. ${ }^{5}$ Other goals are also indirectly but intimately associated with health. The overall MDGs, with emphasis on health-related goals with their targets and indicators, are given in the table 1. Goals 4-6 are directly related to health. Other goals involve the other vital aspects of human development such as poverty reduction, education, environment sustainability, women empowerment and gender equality. Goal 8 identifies actions that donor countries must take to support developing countries to achieve the first seven goals.

\author{
Correspondence: \\ Dr. Abhinav Vaidya, \\ Department of Community Medicine \\ Kathmandu Medical College \\ Duwakot, Bhaktapur, Nepal \\ Email: dr.abhinavaidya@gmail.com \\ Phone: 9841484422
}


Vaidya et al. Halfway up the highway: Can Nepal meet its Health Millennium Development Goals?

Table 1. Millennium Development Goals highlighting the health-related goals ${ }^{3}$

GOAL 1: ERADICATE EXTREME POVERTY AND HUNGER

Target 1: Halve, between 1990 and 2015, the proportion of people whose income is less than one dollar a day

Target 2: Halve, between 1990 and 2015, the proportion of people who suffer from hunger

Indicator $4 \quad$ Prevalence of underweight children under five years of age

Indicator 5 Proportion of population below minimum level of dietary energy consumption

GOAL 2: ACHIEVE UNIVERSAL PRIMARY EDUCATION

Target 3: Ensure that, by 2015, children everywhere, boys and girls alike, will be able to complete a full course of primary schooling

\section{GOAL 3: PROMOTE GENDER EQUALITY AND EMPOWER WOMEN}

Target 4: Eliminate gender disparity in primary and secondary education, preferably by 2005 , and at all levels of education no later than 2015

\section{GOAL 4: REDUCE CHILD MORTALITY}

Target 5: Reduce by two-thirds, between 1990 and 2015, the under-five mortality rate

Indicator 13 Under-five mortality rate

Indicator $14 \quad$ Infant mortality rate

Indicator 15 Proportion of one-year-old children immunized against measles

GOAL 5: IMPROVE MATERNAL HEALTH

Target 6: Reduce by three-quarters, between 1990 and 2015, the maternal mortality ratio

Indicator $16 \quad$ Maternal mortality ratio

Indicator 17 Proportion of births attended by skilled health personnel

GOAL 6: COMBAT HIV/AIDS, MALARIA AND OTHER DISEASES

Target 7: Have halted by 2015 and begun to reverse the spread of HIV/AIDS

Indicator 18 HIV prevalence among pregnant women aged 15-24 years

Indicator 19 Condom use rate of the contraceptive prevalence rate

Indicator 20 Ratio of school attendance of orphans to school attendance of non-orphans aged 10-14 years

Target 8: Have halted by 2015 and begun to reverse the incidence of malaria and other major diseases

Indicator $21 \quad$ Prevalence and death rates associated with malaria

Indicator 22 Proportion of population in malaria-risk areas using effective malaria control measures

Indicator 23 Prevalence and death rates associated with tuberculosis

Indicator $24 \quad$ Proportion of tuberculosis cases detected and cured under DOTS

GOAL 7: ENSURE ENVIRONMENTAL SUSTAINABILITY

Target 9: Integrate principles of sustainable development into country policies/programmes and reverse the loss of environmental resources

Indicator 29 Proportion of population using solid fuels

Target 10: Halve by 2015 the proportion of people without sustainable access to safe drinking-water and sanitation

Indicator 30 Proportion of population with sustainable access to an improved water source, urban and rural

Indicator $31 \quad$ Proportion of population with access to improved sanitation, urban and rural

Target 11: By 2020 to have achieved a significant improvement in the lives of at least 100 million slum dwellers

GOAL 8: DEVELOP A GLOBAL PARTNERSHIP FOR DEVELOPMENT

Target 12: Develop further an open, rule-based, predictable, non-discriminatory trading and financial system

Target 13: Address the special needs of the least developed countries

Target 14: Address the special needs of landlocked countries and small island developing states 
Vaidya et al. Halfway up the highway: Can Nepal meet its Health Millennium Development Goals?

Target 15: Deal comprehensively with the debt problems of developing countries through national and international measures in order to make debt sustainable in the long term

Target 16: In cooperation with developing countries, develop and implement strategies for decent and productive work for youth

Target 17: In cooperation with pharmaceutical companies, provide access to affordable essential drugs in developing countries

Indicator 46 Proportion of population with access to affordable essential drugs on a sustainable basis

Target 18: In cooperation with the private sector, make available the benefits of new technologies, especially information and communications

\section{MDGS AND NEPAL}

Nepal has been committed to achieving the MDGs since it endorsed the Millennium Declaration. A number of steps have been taken since then to align the MDGs with the national planning process. ${ }^{6}$ For example, as the primary medium-term strategy and implementation plan for reaching the MDGs, the country's Tenth Plan/ Poverty Reduction Strategy Paper (PRSP) (2002/03 2006/07) has incorporated the MDGs into its strategic framework. ${ }^{7}$ Similarly, it has already begun to implement three-hear rolling Medium Term Expenditure Framework (MTEF) which helps to link programs and projects more closely with PRSP priorities. Though Nepal has made a notable progress in human development, as reflected in its ascent to $136^{\text {th }}$ place in 2005 from $140^{\text {th }}$ place in 2004 in the Human Development Index ${ }^{8}$ its development has been restricted by a number of constraints including its rugged terrain with insufficient infrastructure, high transport and investment costs, high population growth, weak governance, political instability and insurgency. In the international arena, Nepal draws particular interest for being one of the Least Developed Countries (LDC), a landlocked developing country and a country with environmental vulnerability, and recently for its political upheavals.

\section{Progress of Nepal in achieving the Health MDGs}

The progress of Nepal towards achieving the MDGs can be envisaged from table 2. Nepal has made a significant progress in many health areas such as child mortality and tuberculosis particularly after the implementation of Integrated Management of Childhood Illnesses (IMCI) programme ${ }^{9}$ and DOTS (Directly Observed Treatment Short-course) respectively. ${ }^{10}$ Regarding childhood mortality, remarkable reductions have been made over the last decades mainly due to improvement in diarrhea management, improved immunization, vitamin A supplementation and ARI management. If the ongoing pace is maintained and if the recently launched programmes such as Saving Newborn Lives (SNL) succeed, it is likely that the target on child mortality is met. Similarly, Nepal's significant success in tuberculosis control can be observed from its achievement of global targets of case detection (70\%) and cure rates $(85 \%)$. On the other hand, the progress in control of HIV/AIDS is seriously challenged and the country fears from having a generalized epidemic of the disease from the current 'concentrated epidemic' if the current trend continues. ${ }^{11}$ Maternal health is dependent on how the country makes progress on providing the safe motherhood services such as essential obstetric services. Provision of Basic Emergency Obstetric Care (BEOC) and Comprehensive Emergency Obstetric Care (CEOC) are priority programmes of National Safe Motherhood Plan. ${ }^{11}$

\section{Challenges for Nepal in achieving the MDGs}

The major challenges that lie ahead for achieving the MDGs in Nepal are briefly outlined (Table 2). The foremost challenges in health include the strengthening of the health systems, prioritization of health within overall development and economic policies, mobilization of more resources for health in remote areas, improvement of the quality of health data and development of health strategies that respond to the diverse and evolving needs of the country. ${ }^{13,14}$ In the overall development, the crucial obstacle to overcome would be the ongoing insurgency and conflict in the country because they will have their ill-effect on all developmental activities.

The financial crunch to achieve the goals including the health goals shall be another major uphill task for Nepal. In Nepal's health sector, seventy percent of the total health expenditures come from private out-of-pocket contributions whereas the shares of the government, external development partners and other public sector are $14 \%, 13 \%$ and $3 \%$ respectively. ${ }^{7}$ It has been estimated US dollars 16.1 billion will be required to achieve the goals in Nepal, almost half of which (US dollars 7.6 billion) will have to come from External Development Partners and this requires almost doubling of the present level of external financial support. ${ }^{6}$

\section{Likelihood of Nepal attaining the Health-related MDGs}

On basis of the current trends, the goals on child health, tuberculosis, safe-drinking water and poverty 
Vaidya et al. Halfway up the highway: Can Nepal meet its Health Millennium Development Goals?

will probably be met whereas it is very unlikely that goals on education and HIV/AIDS will be achieved. On the contrary, the targets on huger, education, gender equality, maternal health, malaria and environmental sustainability can be accomplished if the efforts to achieve them can be accelerated. For poverty reduction, investments in pro-poor labour-intensive activities must be encouraged. Hunger minimization can be accomplished only by addressing the root causes of food security. Emphasis on more gender-responsive policies and programmes and implementation of stringent legal and administrative measures to address violence can aid bring down the gender disparities. Investment on maternal health care should be increased so as to accelerate effective referral and emergency obstetric care. Focus should be on wider coverage of Voluntary Counseling and Testing (VCT) and provision of anti-retroviral drugs to combat HIV. Environmental sustainability requires further enhancement of community participation such as Community Forestry Programme.

Table 2. Nepal's indicators in health and health-related MDGs, challenges and likelihood of achieving them ${ }^{6}$

\begin{tabular}{|c|c|c|c|c|c|c|c|c|c|}
\hline Goals. & Targets. indicators & 1990 & 1995 & 2000 & 2005 & $\begin{array}{l}2015 \\
\text { (target) }\end{array}$ & Major Challenges & $\begin{array}{l}\text { Supportive } \\
\text { environment }\end{array}$ & $\begin{array}{l}\text { Likelihood } \\
\text { of achieving } \\
\text { the target }\end{array}$ \\
\hline 1.1 .1 & $\begin{array}{l}\text { Proportion of } \\
\text { population below } \\
\$ 1 \text { (PPP) per day }\end{array}$ & 33.5 & NA & NA & 24.1 & 17 & $\begin{array}{l}\text { - Rapid decrease } \\
\text { in the growth of } \\
\text { non-agricultural } \\
\text { sector } \\
\text { - Increasing } \\
\text { security } \\
\text { expenditures }\end{array}$ & Fair & Likely \\
\hline 1.2 .4 & $\begin{array}{l}\text { Prevalence of } \\
\text { underweight } \\
\text { children under five } \\
\text { years of age }\end{array}$ & 57 & 47 & 53 & NA & 29 & $\begin{array}{l}\text { - Food scarcity } \\
\text { and unequal } \\
\text { distribution } \\
\text { - non-improving }\end{array}$ & & \\
\hline 1.2 .5 & $\begin{array}{l}\text { Proportion of } \\
\text { population below } \\
\text { minimum level } \\
\text { of dietary energy } \\
\text { consumption }\end{array}$ & 49 & NA & 47 & NA & 25 & $\begin{array}{l}\text { agricultural } \\
\text { productivity }\end{array}$ & Fair & Potentially \\
\hline 2.3 .6 & $\begin{array}{l}\text { Net enrolment } \\
\text { ratio in primary } \\
\text { education }\end{array}$ & 64 & 69 & 81 & 84 & 100 & $\begin{array}{l}\text { - education } \\
\text { affected by } \\
\text { insurgency } \\
\text { - 'hard to reach' } \\
\text { children } \\
\text { especially girls }\end{array}$ & Strong & Unlikely \\
\hline \multirow{3}{*}{3.4 .9} & $\begin{array}{l}\text { Ratio of girls to } \\
\text { boys in primary } \\
\text { education } \\
\text { Ratio of girls to }\end{array}$ & 0.56 & 0.66 & 0.79 & 0.86 & 1.0 & $\begin{array}{l}\text { - poor } \\
\text { implementation } \\
\text { of pro-women } \\
\text { measures }\end{array}$ & \multirow{3}{*}{ Fair } & \multirow{3}{*}{ Potentially } \\
\hline & $\begin{array}{l}\text { boys in secondary } \\
\text { education }\end{array}$ & 0.43 & 0.56 & 0.70 & 0.82 & 1.0 & $\begin{array}{l}\text { - persistent gender } \\
\text { disparity at }\end{array}$ & & \\
\hline & $\begin{array}{l}\text { Ratio of girls to } \\
\text { boys in tertiary } \\
\text { education }\end{array}$ & 0.32 & NA & 0.28 & NA & 1.0 & $\begin{array}{l}\text { all levels and } \\
\text { sectors } \\
\text { - violence, abuse } \\
\text { and exploitation }\end{array}$ & & \\
\hline 4.5 .13 & $\begin{array}{l}\text { Under-five mortality } \\
\text { rate }\end{array}$ & 162 & 118 & 91 & $61^{\mathrm{a}}$ & 54 & $\begin{array}{l}\text { - lowering neonatal } \\
\text { mortality }\end{array}$ & & \\
\hline 4.5 .14 & $\begin{array}{l}\text { Infant mortality } \\
\text { rate }\end{array}$ & 108 & 79 & 64 & $48^{\mathrm{a}}$ & 34 & $\begin{array}{l}\text { - improving child } \\
\text { nutrition }\end{array}$ & & \\
\hline 4.5 .15 & $\begin{array}{l}\text { Proportion of one- } \\
\text { year-old children } \\
\text { immunized against } \\
\text { measles }\end{array}$ & 42 & 57 & 71 & 85 & $>90$ & $\begin{array}{l}\text { - improving and } \\
\text { maintaining } \\
\text { high Expanded } \\
\text { Programme on } \\
\text { Immunization } \\
\text { Coverage }\end{array}$ & Strong & Likely \\
\hline
\end{tabular}


Vaidya et al. Halfway up the highway: Can Nepal meet its Health Millennium Development Goals?

$\begin{array}{llllllll}5.6 .16 & \begin{array}{l}\text { Maternal mortality } \\ \text { ratio }\end{array} & 550 & 539 & 415 & 280^{\mathrm{a}} & 213 \\ 5.6 .17 & \begin{array}{l}\text { Proportion of births } \\ \text { attended by skilled } 7 \\ \text { health personnel }\end{array} & 9 & 11 & 20 & 60\end{array}$

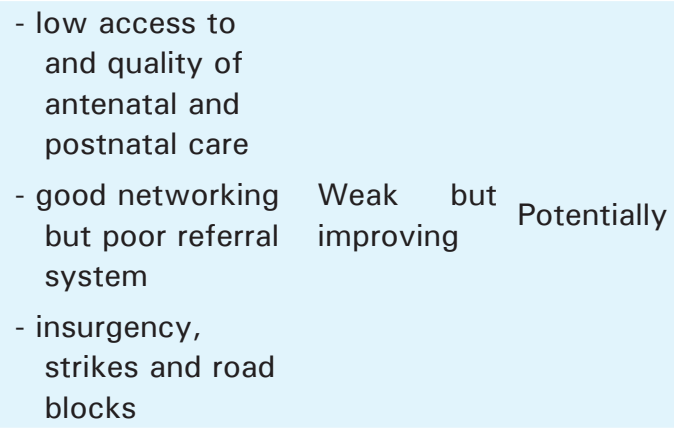

Goals. Targets. indicators
2015 Major

(target) Challenges

6.7.18 HIV prevalence $\begin{array}{lllll}\text { among } 15-49 \text { years NA NA } & 0.29 & 0.5\end{array}$ of age (\%) b

6.7.19 Contraceptive prevalence rate including condom use $\begin{array}{llll}24 & 29 & 39 & \text { NA }\end{array}$

6.7.20 Ratio of school attendance of orphans to school attendance of non-

NA NA NA NA orphans aged 10-14 years $^{d}$

Prevalence of

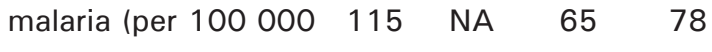

6.8.21 people at risk)

Death rates

associated with

malaria

Proportion of population in malaria-

6.8 .22 risk areas using effective malaria NA 9.75 $6.94 \quad 11.4$ prevention and treatment measures

Prevalence of tuberculosis

6.8.23 Death rates associated with tuberculosis Proportion of tuberculosis cases detected under DOTS (Directly Observed Treatment Short-

$\begin{array}{ll}\text { 6.8.24 } & \begin{array}{l}\text { course) } \\ \text { Proportion of }\end{array}\end{array}$ tuberculosis cases cured under DOTS (Directly Observed $\begin{array}{llll}\text { NA } & \text { NA } & 89 & 88\end{array}$

- poor surveillance system

- limited awareness

Weak but improving

Unlikely

- limited access to care and support services

Supportive of environment achieving the target

- conflict causing displacement to malaria-prone areas

- resurgence of falciparum

Weak but improving

Potentially malaria

- increasing resistance to routine drugs
Likelihood Treatment Shortcourse) 
Vaidya et al. Halfway up the highway: Can Nepal meet its Health Millennium Development Goals?

population using solid $75 \quad 67.74 \quad 67.74 \quad 69.1$

fuels ${ }^{e}$

Proportion of

population with

sustainable access to $90 \quad 96 \quad 86 \quad 93 \quad 95$

an improved water

7.10.30 source, urban

Proportion of

population with

$\begin{array}{llllll}\text { sustainable access to } & 43 & 68 & 71 & 79 & 72\end{array}$

an improved water

source, rural

Proportion of

population with

access to improved

34

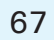

80

81

- limited access

and sustainable

development

Fair

Potentially

of renewable

energy

sanitation, urban

7.10.31 Proportion of population with

access to improved

3

18

25

30

52

sanitation, rural

a NDHS 2006'2, b Data not available for the recommended indicator (HIV prevalence among pregnant women aged 15-24 years), c No separate data available for the recommended indicator (Condom use rate of the contraceptive prevalence rate), d Data on this indicator currently unavailable, e Data for people using wood as their main fuel, NA Data not available

Improving government healthcare spending and investments in human and infrastructure capital are vital to achieving the health related MDGs, as is improving resource allocations within the health sector through more equitable allocations targeted to primary care and specific populations in geographical areas, mainly the poorest and the neglected communities. ${ }^{15}$ Appropriate technology, cost-effective remedies such as antibiotics, immunizations, basic hygiene, nutrition, prenatal and obstetric care are available to prevent death and diseases; however the problem is not the lack of intervention but that of universal availability of those interventions. ${ }^{16}$ In addition, to provide a sustainable development of health financing and resource allocation across the whole sector, public investments must also be increased. For this, possibilities of assuming of a certain fraction of the health expenditure by elected local bodies such as District Development Committee and Village Development Committee must be explored.
In the same way, alternate financing schemes such as Community Drug Programme and Community Health Insurance must be encouraged. ${ }^{17}$

\section{CONCLUSION}

Accomplishing the health-related MDGs thus requires more than escalating public health investment and a makeover in underlying values and societal structures. Progress towards health for all calls for a strong commitment and assurances by the stakeholders to protect all individuals especially the most deprived and excluded. In addition, the financial resources provided by the international community to support health spending must be sustainable such that it encourages and provides support and not dependency. Last but not the least, achieving the MDGs for health also demands a democratic system that are inclusive and publicly accountable and that ensures free and independent media and civil society and transparent policy making. 
Vaidya et al. Halfway up the highway: Can Nepal meet its Health Millennium Development Goals?

\section{REFERENCES}

1. Carr D. Improving the health of the world's poorest people. Health Bulletin 2004; Population Reference Bureau, Washington, DC; 2004.

2. United Nations Population Division. World Population Prospects: The 2002 Revision highlights. UNDP; 2002.

3. UN Millennium Project. 2005. Investing in Development: A Practical Plan to Achieve the Millennium Development Goals. New York.

4. World Health Organization. Health and Millennium Development Goals 2005: Keep The Promise. WHO: Geneva, Switzerland; 2005.

5. World health Organization. Measuring Progress towards the Health Millennium Development Goals [homepage on the internet]. Geneva, Switzerland: Health Policy, Development and Services, WHO; [updated 2007 Dec 22; cited 2008 Jan 13]. Available from: http://www.who.int/mdg/measuring progress/en/index.html.

6. National Planning Commission (NPC) [Nepal] and United Nations Country Team of Nepal. 2005. Nepal Millennium Development Goals Progress Report 2005. Kathmandu, Nepal: HMG Nepal, / United Nations Development Programme [UNDP]; 2005.

7. National Planning Commission (NPC) [Nepal]. The Tenth Plan (Poverty Reduction Strategy Paper):2002-2007. Kathmandu, Nepal: HMG Nepal; 2003.

8. United Nations Development Programme. Human Development Report 2005: International cooperation at a crossroads Aid, trade and security in an unequal world. New York; 2005.
9. Ministry of Health [Nepal].2003. IMCI Programme Annual Report. Kathmandu, Nepal: IMCI Section, Child Health Division, Department of Health Services, HMG Nepal; 2003.

10. Ministry of Health [Nepal].2003. National Tuberculosis Control Programme Annual Report. Kathmandu, Nepal: National Tuberculosis Centre, Department of Health Services, HMG Nepal; 2003.

11. Ministry of Health [Nepal]; Department of health services: Annual Report of Department of health services 2002-3, Kathmandu, Nepal: Ministry of health and population; 20034.

12. Ministry of Health and Population (MOHP) [Nepal], New ERA, and Macro International Inc. 2007. Nepal Demographic and Health Survey 2006. Kathmandu, Nepal: Ministry of Health and Population, New ERA, and Macro International Inc; 2007.

13. World Bank. Global Monitoring Report 2005: Millennium Development Goals: From Consensus to Momentum. Washington DC; 2005.

14. United Nations Development Programme. Millennium Development Goals: Progress, Reversals and Challenges. New York; 2005.

15. JD Sachs. Health in the Developing World: Achieving the Millennium Development Goals. Bull WHO 2004; 82:947952.

16. C Nullis-Kapp. The knowledge is there to achieve the development goals, but is the will? Bull WHO 2004; 82: 8046.

17. Ministry of Health [Nepal]; Nepal Health Sector ProgrammeImplementation Plan 2004-2009. Kathmandu, Nepal: Ministry of Health; 2004. 